\title{
PENGARUH PENGELOLAAN KELAS TERHADAP MINAT DAN HASIL BELAJAR BAHASA INDONESIA SISWA KELAS VIII SMP SWASTA METHODIST BERASTAGI
}

\author{
Mia Audina Br Surbakti ${ }^{1}$, Berman Hutahaean ${ }^{2}$ \\ *1. Penulis \\ *2. Pembimbing \\ Program Studi Pendidikan Bahasa Indonesia,FakultasKeguruan dan Ilmu Pendidikan, Universitas Katolik Santo \\ Thomas, Jl. Setia Budi No.479-F Tanjung Sari Medan - Kode Pos No.20132, email-audinamia@yahoo.co.id
}

Abstrak

Penelitian ini bertujuan untuk mendeskripsikan pengaruh pengelolaan kelas terhadap minat dan hasil belajar bahasa Indonesia siswa kelas VIII SMP Swasta Methodist Berastagi Tahun Ajaran 2018/2019. Pendekatan penelitian yang digunakan adalah kuantitatif dengan metode penelitian Kuantitatif Statistik. Objek dalam penelitian ini adalah siswa/siswi kelas VIII dengan jumlah 106 orang. Sampel penelitian sebanyak 36 siswa ditentukan berdasarkan teknik purposive sampling. Instrumen pengumpulan data dalam penelitian ini adalah menggunakan angket, dokumen dan wawancara. Sesuai perumusan masalah penelitian ini ditemukan hasil penelitian sebagai simpulan: (1) minat dan hasil belajar siswa di SMP Swasta Methodist Berastagi sangat kuat 14 orang dan kuat 22 orang; (2) pengelolaan kelas yang dilakukan guru pada mata pelajaran bahasa Indonesia di SMP Swasta Methodist Berastagi sangat kuat 9 orang dan dan kuat 27 orang; (3) pengaruh pengelolaan kelas terhadap minat dan hasil belajar bahasa Indonesia siswa kelas VIII SMP Swasta Methodist Berastagi sudah baik Pengaruh pengelolaan kelas terhadap minat sebesar $24,9 \%$, pengelolaan kelas terhadap hasil belajar 6,6\%.

\section{Kata kunci : pengelolaan kelas, minat belajar, hasil belajar}

\begin{abstract}
This study aims to describe the effect of classroom management on the interests and learning outcomes of Indonesian students of the eighth grade students of Methodist Berastagi Private Middle School Academic Year 2018-1919. The research approach used is quantitative with the Quantitative Statistics research method. Objects in this study were students of class VIII with a total of 106 people. The research sample consisted of 36 students determined based on purposive sampling technique. Data collection instruments in this study were using questionnaires, documents and interviews. In accordance with the formulation of the research problem, the results of the study were found as conclusions: (1) the interest and learning outcomes of students in Berastagi Methodist Private Junior High School were very strong, 14 people and 22 strong; (2) the classroom management conducted by the teacher in the Indonesian language subject at Berastagi Methodist Private Junior High School was 9 strong and 27 strong; (3) the influence of classroom management on interest and learning outcomes of Indonesian students of class VIII Berastagi Methodist Private Junior High School has had a good effect on classroom management on interest of $24.9 \%$, classroom management of learning outcomes $6.6 \%$.
\end{abstract}

Keywords: classroom management, interest in learning, learning outcomes 


\section{PENDAHULUAN}

Seorang guru hendaknya mampu mengarahkan dan membimbing siswa untuk aktif dalam kegiatan belajar mengajar, sehingga tercipta suasana serta interaksi yang baik antara guru dengan siswa maupun siswa dengan siswa. Keaktifan serta terjadinya perubahan prilaku yang selaras dengan tujuan pengajaran yang hendak dicapai merupakan suatu hal yang menandai terjadinya proses pembelajaran. Selain itu, guru menjadi faktor yang berpengaruh terhadap prestasi belajar siswa, serta sekolah hendaknya menguasai keterampilan mengajar dan menerapkan dalam proses belajar mengajar. Salah satu yang harus dimiliki guru adalah keterampilan mengelola kelas mengingat tugas guru di dalam kelas adalah membelajarkan siswa dengan menyediakan kondisi belajar yang optimal, sesuai tujuan pembelajaran yang hendaknya dicapai.

Menurut Arikunto (1988: 67) pengelolaan kelas adalah suatu usaha yang dilakukan oleh penanggung jawab kegiatan belajar mengajar atau membantu dengan maksud agar tercapai kondisi optimal sehingga dapat terlaksana kegiatan belajar seperti yang diharapkan. Menurut Burhanuddin pengelolaan kelas merupakan salah satu keterampilan guru dalam menciptakan dan memelihara kondisi belajar yang optimal dan mengembalikannya bila terjadi gangguan dalam proses belajar mengajar. Guru yang berperan sebagai pengelola kelas, hendaknya dapat menyediakan fasilitas yang memungkinkan kemudahan kegiatan belajar siswa, dan lingkungan belajar yang menyenangkan siswa sehingga siswa dapat mengikuti kegiatan belajar mengajar dengan aman dan nyaman.

Pengelolaan kelas dilakukan untuk menciptakan lingkungan belajar yang kondusif bagi siswa sehingga tercapai tujuan pembelajaran yang efektif dan efisien. Penciptaan lingkungan belajar dapat dilakukan dengan menata kondisi kelas agar siswa lebih antusias dalam mengikuti pembelajaran. Penata kelas termasuk dalam pengelolaan kelas secara fisik. Pengelolaan kelas secara fisik berupa pengaturan ruang kelas yang meliputi pengaturan tempat duduk, pengaturan alat-alat pengajaran, penataan keindahan dan kebersihan kelas serta ventilasi dan tata cahaya (Syaipul Bahri Djamrah \& Aswan Zain, 2013: 177).

$$
\text { Pengelolaan kelas dengan }
$$
pengaturan siswa dilakukan apabila adanya gangguan di kelas dan guru berusaha untuk mengembalikannya sehingga suasana kelas tetap kondusif. Pengelolaan kelas yang 
dilakukan oleh guru diharapkan dapat menciptakan kondisi kelas yang diharapkan mencakup lingkungan, emosional, intelektual serta sosial di dalam kelas. Keberhasilan guru dalam mengajar di kelas bukan hanya ditentukan dari pengetahuan tentang kurikulum, metode mengajar, media pembelajaran, wawasan tentang materi yang akan disampaikan kepada anak didik, tetapi guru juga harus menguasai cara mengelola kelas. Pengelolaan kelas memiliki peranan penting dalam keberhasilan proses pembelajaran dimana guru mampu menciptakan suasana belajar yang aktif, kreatif, dan menyenangkan(Sudarsana et al., 2018) dan (Tonni Limbong, 2018).

Untuk memperoleh kegiatan belajar mengajar yang optimal, maka diperlukan pengelolaan kelas yang efektif. Pengelolaan kelas yang efektif akan menghasilkan pembelajaran yang efektif pula. Untuk menciptakan pengajaran yang efektif dapat dilakukan dengan kegiatan-kegiatan yang dapat menciptakan serta mengkondisikan kelas yang optimal bagi terjadinya proses belajar mengajar, antara lain: pemberian penghargaan kepada siswa yang menyelesaikan tugas tepat waktu, hubungan/interaksi yang baik antara guru dengan siswa maupun siswa dengan siswa, dan mampu mengatur siswa serta mengendalikannya sehingga tercipta suasana yang menyenangkan selama proses pembelajaran berlangsung.

\section{KAJIAN KEPUSTAKAAN}

\section{Kajian Teori}

\section{Pengertian Pengelolaan Kelas}

Ada beberapa definisi tentang pengelolaan kelas yang dikemukakan oleh beberapa pakar. Menurut Sudirman pengelolaan kelas adalah upaya mendayagunakan potensi kelas, ditambah lagi oleh Hadari Nawawi dengan mengatakan bahwa kegiatan manajemen atau pengelolaan kelas dapat diartikan sebagai kemampuan guru atau wali kelas dalam mendayagunakan potensi kelas berupa pemberian kesempatan yang seluas luasnya pada setiap personal untuk melakukan kegiatan-kegiatan yang kreatif dan terarah sehingga waktu dan dana yang tersedia dapat dimanfaatkan secara efisien untuk melakukan kegiatan-kegiatan kelas yang berkaitan dengan kurikulum dan perkembangan murid. (Aswan Zain 2013: 177)

Suharsimi Arikunto juga berpendapat bahwa pengelolaan kelas adalah suatu usaha yang dilakukan oleh penanggung jawab kegiatan belajar mengajar atau yang membantu dengan maksud agar dicapai kondisi optimal sehingga dapat terlaksana kegiatan belajar seperti yang di harapkan. 
Suharsimi memahami pengelolaan kelas ini dari dua segi, yaitu pengelolaan yang menyangkut siswa, dan pengelolaan fisik (ruangan, perabot, alat pelajaran). Menurutnya membuka jendela agar udara segera dapat masuk ke ruangan, menyalakan lampu listrik, mengatur tempat duduk, merupakan kegiatan pengelolaan kelas secara fisik. (Aswan Zain 2013: 177)

Berdasarkan beberapa pendapat di atas dapat disimpulkan bahwa pengelolaan kelas merupakan suatu kemampuan yang dimiliki oleh guru dalam menciptakan, mengkondisikan serta mengembalikan suasana kelas dan belajar siswa yang efektif agar tetap menyenangkan dan optimal.

\section{Tujuan Pengelolaan Kelas}

Pengelolaan kelas bukan sekedar bertujuan untuk mengatur kondisi kelas, tetapi juga meliputi pengaturan berbagai komponen (Jurnal, n.d.). Mengelola kelas berarti menciptakan dan memelihara kondisi kelas yang memungkinkan berlangsungnya proses pembelajaran secara efektif. Dengan demikian, pengelolaan kelas sebenarnya memiliki tujuan yang kompleks. Dalam buku Widiasworo (2018: 17), menurut Ahmad ada beberapa tujuan pengelolaan kelas, sebagai berikut:

1. Mewujudkan situasi kelas, baik sebagai individu maupun kelompok.
2. Menghilangkan berbagai hambatan yang dapat menghalangi terwujudnya interaksi pembelajaran.

3. Menyediakan dan mengatur fasilitas serta perabot belajar yang mendukung dan memungkinkan.

4. Membina dan membimbing sesuai latar belakang sosial, ekonomi, budaya.

\section{Pengertian Minat}

Minat adalah suatu rasa lebih suka dan rasa keterikatan pada suatu hal atau aktivitas, tanpa ada yang menyuruh. Minat pada dasarnya adalah penerimaan akan suatu hubungan antara diri sendiri dengan sesuatu di luar diri. Suatu minat dapat diekspresikan melalui suatu pernyataan yang menunjukkan bahwa siswa lebih menyukai suatu hal daripada hal lainnya, dapat pula dimanifulasikan melalui partisipasi dalam suatu aktivitas. Benih dari suatu sifat yang baru akan tampak nyata jika ya mendapatkan kesempatan atau kemungkinan untuk berkembang. Mustaqim (2012: 140)

Minat adalah kecenderungan jiwa yang tetap untuk memperhatikan dan mengenang beberapa aktivitas atau kegiatan. Seseorang yang berminat terhadap suatu aktivitas dan memperhatikan itu secara konsisten dengan rasa senang. Minat dapat menjadi sebab sesuatu kegiatan dan sebagai hasil dari keikutsertaan dalam suatu kegiatan. Karena itu minat belajar adalah 
kecenderungan hati untuk belajar untuk mendapatkan informasi, pengetahuan, kecakapan melalui usaha, pengajaran atau pengalaman.

Menurut Nasution belajar sebagai perubahan kelakuan berkat pengalaman dan latihan. Dalam Kamus Besar Bahasa Indonesia disebutkan bahwa belajar adalah berusaha memperoleh kepandaian, berlatih, dan berubah tingkah laku atau tanggapan yang disebabkan oleh pengalaman. Dengan belajar tindakan atau perilaku siswa berubah menjadi baik. Berhasil atau tidaknya perubahan baik itu tergantung pada siswa itu sendiri dan tergantung pula oleh beberapa faktor yang mempengaruhinya. Kondisi kejiwaan sangat dibutuhkan dalam proses belajar mengajar. Itu berarti bahwa minat sebagai suatu aspek kejiwaan melahirkan daya tarik tersendiri untuk memperhatikan suatu obyek tertentu.

\subsubsection{Pengertian Hasil Belajar Siswa}

Secara etimologis, hasil belajar merupakan gabungan dari kata hasil dan belajar. (Kridalaksana,1990: 14) hasil adalah sesuatu yang diadakan (dibuat, dijadikan) akibat usaha. Belajar adalah berusaha memperoleh kepandaian atau ilmu untuk merubah tingkah laku atau tanggapan yang disebabkan pengalaman. Berdasarkan pengertian di atas maka dapat diperoleh suatu pengertian bahwa hasil belajar adalah kemampuan yang dimiliki oleh siswa setelah belajar, yang wujudnya berupa kemampuan kognitif, afektif, dan psikomotor yang disebabkan oleh pengalaman. Hasil belajar adalah pola-pola perbuatan, nilai-nilai, pengertian-pengertian, sikap-sikap, apresiasi dan keterampilan. Merujuk pemikiran Gagne Supriono (2009: 33), hasil belajar itu berupa:

1. Informasi verbal yang kapabilitas mengungkapkan pengetahuan dalam bentuk bahasa, baik lisan maupun tertulis. Kemampuan merespons secara spesifik terhadap rangsangan spesifik. Kemampuan tersebut tidak memerlukan manipulasi simbol, pemecahan masalah maupun penerapan aturan.

2. Keterampilan intelektual yaitu kemampuan mempresentasikan konsep dan lambang. Kemampuan intelektual terdiri dari kemampuan mengategorisasi, kemampuan analitis sintesis fakta-konsep dan mengembangkan prinsip-prinsip keilmuan. Keterampilan intelektual merupakan kemampuan melakukan aktivitas kognitif bersifat khas.

3. Strategi kognitif yaitu kecakapan menyalurkan dan mengarahkan aktivitas kognitifnya sendiri. Kemampuan ini meliputi penggunaan konsep dan kaidah dalam memecahkan masalah. 
4. Keterampilan motorik yaitu kemampuan melakukan serangkaian gerak jasmani dalam urusan dan koordinasi, sehingga terwujud otomatisme gerak jasmani.

5. Sikap adalah kemampuan menerima atau menolak objek berdasarkan penilaian terhadap objek tersebut. Sikap berupa kemampuan menginternalisasi dan eksternalisasi nilai-nilai. Sikap merupakan kemampuan menjadikan nilai-nilai sebagai standar perilaku.

\section{Pendekatan dan Metode Penelitian}

Pendekatan penelitian ini adalah pendekatan penelitian kuantitatif. Sugiyono (2009: 14) mengatakan pendekatan kuantitatif dapat diartikan sebagai penelitian yang berlandaskan pada filsafat positivisme, digunakan untuk meneliti pada populasi atau sampel tertentu, teknik pengambilan sampel pada umumnya dilakukan secara random, pengumpulan data menggunakan instrumen penelitian, analisis data bersifat kuantitatif/statistik dengan tujuan untuk menguji hipotesis yang telah ditetapkan. Metode Penelitian adalah sebagai suatu cara yang digunakan untuk mengumpulkan data guna mencapai tujuan penelitian. Sehubungan dengan judul penelitian ini, penulis menggunakan metode Kuantitatif Statistik, yaitu suatu cara atau teknik untuk mendapatkan gejala-gejala yang ada pada masa sekarang.

\section{Desain Penelitian}

Desain penelitian yang digunakan pada penelitian ini adalah desain penelitian kuantitatif untuk studi evaluatif. Dalam desain penelitian evaluatif, peneliti harus membuat desain pernyataan atau pertanyaan dalam bentuk angket. Penelitian kuantitatif digunakan untuk mengetahui pengaruh pengelolaan kelas terhadap minat dan hasil belajar bahasa Indonesia siswa kelas VIII SMP Swasta Methodist Berastagi.

Menurut Suharsimi Arikunto (1997: 97), terdapat dua variabel yang dipengaruhi oleh suatu treatment, yaitu variabel bebas (X) dan variabel terikat (Y). Variabel bebas merupakan variabel yang diselidiki pengaruhnya terhadap gejala atau permasalahan yang ada, sedangkan variabel terikat merupakan suatu variabel yang akan muncul sebagai pengaruh dari variabel bebas. Berkaitan dengan pendapat tersebut, pada penelitian ini terdapat dua variabel, yaitu variabel bebas (X1 dan X2) adalah pengaruh pengelolaan kelas dan mina belajar, dan variabel terikat (Y) adalah hasil belajar siswa.

\section{HASIL PENELITIAN DAN PEMBAHASAN}


1. Pengaruh Minat dan Hasil Belajar Siswa Di SMP Swasta Methodist Berastagi

Dilihat dari hasil rekapitulasi minat belajar siswa SMP Swasta Methodist Berastagi bahwa minat belajar siswa dikategorikan sangat kuat dimana minat adalah kecenderungan seseorang terhadap objek atau suatu kegiatan yang digemari yang disertai dengan perasaan senang, adanya perhatian dan keaktifan. Dimana siswa yang memiliki minat belajar sangat kuat adalah 14 0rang dan siswa yang minat belajarnya kuat adalah 22 orang. Maka dapat di simpulkan bahwa minat belajar siswa sangat kuat di SMP Swasta Methodist Berastagi.

Dari hasil penelitian yang sudah dilaksanakan, maka minat belajar siswa sudah dikatakan bagus. Karena lebih banyak yang memiliki minat dalam belajar, dari 27 butir pernyataan hanya 4 orang siswa yang mempunyai minat belajar yang rendah. Dari minat belajar yang dimiliki siswa maka hasil belajar siswa juga akan meningkat karena keinginannya dalam belajar masih ada.

\section{Pengaruh Pengelolaan Kelas yang Dilakukan Guru Pada Mata Pelajaran Bahasa Indonesia Di SMP Swasta Methodist Berastagi}

Dilihat dari hasil rekapitulasi minat belajar siswa SMP Swasta Methodist
Berastagi bahwa pengelolaan dalam belajar siswa dikategorikan sangat kuat dimana pengelolaan kelas adalah kecenderungan seseorang terhadap objek atau suatu kegiatan yang dilakukan oleh guru bahasa Indonesia yang disertai dengan perasaan senang, adanya perhatian dan keaktifan siswa dalam belajar. Di mana siswa yang memilih pengelolaan kelas sangat kuat adalah 9 orang dan siswa yang minat belajarnya kuat adalah 27 orang. Maka dapat disimpulkan bahwa pengelolaan kelas yang dilakukan guru dalam belajar sudah baik di SMP Swasta Methodist Berastagi.

Dari data yang diperoleh maka pengelolaan yang dilakukan oleh guru bahasa Indonesia sudah baik. Karena dalam angket pernyataan yang peneliti sebarkan kepada siswa hampir semua siswa yang telah memberikan penilaian yang baik terhadap guru tersebut. Maka dapat disimpulkan bahwa pengelolaan kelas yang dilakukan guru bahasa Indonesia SMP Swasta Methodist Berastagi sudah baik.

\section{Pengaruh Pengelolaan Kelas Terhadap Minat dan Hasil Belajar Bahasa Indonesia Siswa Kelas VIII SMP Swasta Methodist Berastagi}

Dari data yang diperoleh maka pengelolaan yang dilakukan oleh guru bahasa Indonesia sudah baik. Karena dalam 
angket pernyataan yang peneliti sebarkan kepada siswa hampir semua siswa yang telah memberikan penilaian yang baik terhadap guru tersebut. Maka dapat disimpulkan bahwa pengelolaan kelas yang dilakukan guru bahasa Indonesia SMP Swasta Methodist Berastagi sudah baik. Dari segi minat belajar bahasa Idonesia siswa juga banyak siswa yang sudah memiliki minat belajar yang baik. Dengan dilakukan pengelolaan kelas yang di terapkan oleh guru bahasa Indonesia minat belajar siswa juga sudah meningkat.

Hasil pengujian hipotesis pertama menunjukkan bahwa minat belajar siswa SMP Swasta Methodist Berastagi semester ganjil menunjukkan bahwa hasil yang unggul didominasi dari siswa. Sedangkan hipotesis yang kedua adalah pengelolaan kelas oleh guru berpengaruh secara signifikan terhadap minat belajar siswa SMP Swasta Methodist Berastagi. Berdasarkan tabel di atas bahwa nilai konstanta adalah 52,019 , pengelolaan kelas $(0,116)$ dan minat belajar $(0,203)$.

$\mathrm{Y}=52,019+0,116 \mathrm{X} 1+0,203 \mathrm{X} 2$

Menyatakan bahwa jika nilai variabel bebas $\mathrm{X} 1$ dan $\mathrm{X} 1$ = 0 maka nilai $\mathrm{Y}$ adalah 52,019. Dalam kata lain bahwa nilai hasil belajar $\mathrm{X}$ tanpa pengelolaan kelas dan minat belajar adalah 52,019
Koefisien regresi variabel pengelolaan kelas (X1) sebesar 0,116 artinya bahwa peningkatan satu unit variabel pengelolaan kelas dengan asumsi variabel bebas lain konstanta akan menyebabkan kenaikan hasil belajar sebesar 0,116.

Koefisien regresi variabel minat belajar atau X2 sebesar 0,203 artinya bahwa peningkatan satu unit variabel minat belajar dengan asumsi variabel bebas lainnya konstanta akan menyebabkan kenaikan hasil belajar sebesar 0,203.

\section{Simpulan}

Berdasarkan hasil analisis data dalam bab 1V dari penelitian yang berjudul "Pengaruh Pengelolaan Kelas terhadap Minat dan Hasil Belajar Bahasa Indonesia Siswa SMP Swasta Methodist Berastagi Tahun Ajaran 2018/2019”, diperoleh Simpulan:

1. Hasil minat dan hasil belajar siswa SMP Swasta Methodist Berastagi tahun ajaran 2018/2019 dikategorikan sangat kuat. Dilihat dari hasil rekapitulasi minat belajar siswa SMP Swasta Methodist Berastagi bahwa minat belajar siswa dimana siswa yang memiliki minat belajar sangat kuat adalah 14 orang dan siswa yang minat belajarnya kuat adalah 22 orang.

2. Hasil pengelolaan kelas terhadap hasil belajar siswa di SMP Swasta Methodist 
Berastagi dikategorikan sangat kuat.

Dilihat dari hasil rekapitulasi minat belajar siswa SMP Swasta Methodist Berastagi bahwa pengelolaan sangat kuat adalah 9 orang dan siswa yang minat belajarnya kuat adalah 27 orang.

3. Hasil pengelolaan kelas terhadap minat dan hasil belajar bahasa indonesia siswa kelas VIII SMP Swasta Methodist Berastagi sudah baik. Berdasarkan data yang didapat mengenai pengelolaan kelas oleh guru di SMP Swasta Mthodist Berastagi. Dengan hasil pengelolaan kelas Sangat Baik sementara siswa memiliki minat belajar yang baik juga, maka hasil dari keseluruhan yang didapat peneliti adalah bahwa terdapat pengaruh antara pengelolaan kelas terhadap minat dan hasil belajar bahasa Indonesia siswa kelas VIII SMP Swasta Methodist Berastagi

\section{DAFTAR KEPUSTAKAAN}

Arifin, Zainal. 2011. Evaluasi Instruksional: Prinsip-Teknik-Prosedur. Bandung: Remaja Rosdakarya.

Arikunto, Suharsimi. 2009. Dasar-Dasar Evaluasi Pendidikan. Jakarta: Bumi Aksara.

Arikunto, Suharsimi. 2017. Prosedur Penelitian Suatu Pendekatan Praktik. Rev. Jakarta: Rineka Cipta.

Kridalaksana. 2008. Kamus Linguistik. Jakarta: Gramedia Pustaka Utama.
Mustaqim. 2012. Psikologi Pendidikan. Yogyakarta: Pustaka Pelajar.

Sugiyono. 2017. Metode Penelitian Pendidikan Pendekatan Kuantitatif, Kualitatif dan R\&D. Bandung: Alfabeta.

Jurnal. (n.d.). PENGGUNAAN MEDIA PEMBELAJARAN BERBASIS VIDEO TERHADAP AKTIVITAS DAN HASIL BELAJAR GEOGRAFI. Retrieved from https://media.neliti.com/media/publicati ons/250577-penggunaan-mediapembelajaran-berbasis-v-4bece778.pdf

Sudarsana, I. K., Dewi, N. L. P. S. S., Sukarmiasih, N. P., Resna, I. K., Arini, I. A. M. P., Restiti, N. W., ... Limbong, T. (2018). Paradigma Pedidikan Bermutu Berbasis Teknologi Pendidikan. Jayapangus Press Books, $O(0)$. Retrieved from http://books.jayapanguspress.org/index. php/publisher/article/view/19

Tonni Limbong. (2018). PENDIDIKAN BERBASIS IT DAN ETIKANYA . Jayapangus Press, 1(1), 52-79.

Supriyono. 2009. Cooperative Learning Teori dan Aplikasi. Yogyakarta: Pustaka Pelajar.

Widiasworo, Erwin. 2018. Cerdas Pengelolaan Kelas. Yogyakarta: DIVA Pres.

Zain Aswan \& Djamrrah Bahri Syaiful. 2013. Strategi Belajar Mengajar. Jakarta: Rineka Cipta. 